\title{
Denton A. Cooley: In memoriam
}

\author{
Joseph S. Coselli, MD
}

\footnotetext{
From the Division of Cardiothoracic Surgery, Michael E. DeBakey Department of Surgery, Baylor College of Medicine; Section of Adult Cardiac Surgery, Department of Cardiovascular Surgery, Texas Heart Institute; and CHI St. Luke's Health-Baylor St. Luke's Medical Center, Houston, Tex.

Received for publication Jan 27, 2017; accepted for publication Jan 30, 2017; available ahead of print March 6, 2017.

Address for reprints: Joseph S. Coselli, MD, One Baylor Plaza, BCM 390, Houston, TX 77030 (E-mail: jcoselli@ bcm.edu).

J Thorac Cardiovasc Surg 2017;153:1231-40

$0022-5223 / \$ 36.00$

Copyright (C) 2017 by The American Association for Thoracic Surgery

http://dx.doi.org/10.1016/j.jtcvs.2017.01.043
}

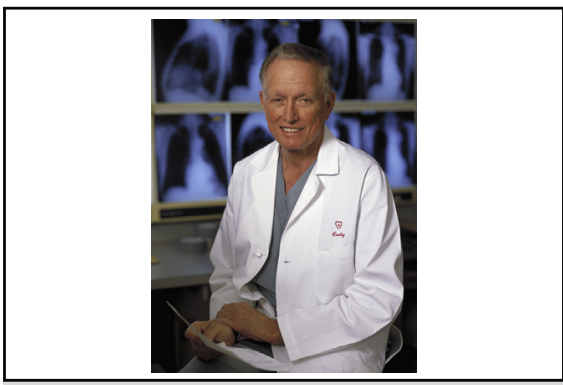

Denton Arthur Cooley (1920-2016), legendary surgeon who founded the Texas Heart Institute.

\section{Central Message}

Denton A. Cooley has died at age 96 (August 22, 1920-November 18, 2016). A pioneering cardiothoracic surgeon, he founded the Texas Heart Institute and put Houston at the forefront of medical progress.
Dr Denton A. Cooley, the distinguished cardiothoracic surgeon who put Houston at the forefront of medical achievement, died on November 18, 2016. He was 96 years old.

Denton Arthur Cooley was born on August 22, 1920, in Houston, Texas (Figure 1). His father, Dr Ralph Clarkson Cooley, was a prominent local dentist who had a close friendship with Dr Ernst William Bertner (who would go on to found the Texas Medical Center in the mid-1940s). Dr Cooley's grandfather, Daniel Denton Cooley, was a key developer of the Houston Heights neighborhood in the late 19th century. Dr Cooley was a life-long Houstonian, leaving the city only briefly for his medical education and military service, and he fostered the city's development into what it eventually became: One of the premier locations for pioneering heart surgery. His efforts to establish the feasibility of cardiac transplantation and prosthetic replacement became a revolutionary feat of medicine. For much of Dr Cooley's life, he was discussed with regard to not only his personal achievements but also his relationship to another noted surgeon, Dr Michael DeBakey, although the 2 surgeons spent much of their lives apart because of a disagreement over the use of the total artificial heart (TAH). Without a doubt, the competition between these 2 larger-than-life men helped build the Texas Medical Center into the world-renowned establishment that it is today.

While attending medical school, Dr Cooley once went to a night club in Galveston. While he was there, a man who turned out to be the leader of a notable organized crime syndicate in the area came up to him. When he found out that the young Denton Cooley was studying to become a doctor, the crime boss chastised him for being at the night club, saying that he would never go where he wanted to go in life if he was spending time at places like this. ${ }^{1}$
Through his embarrassment over this chastisement, Dr Cooley learned his lesson and went on to become what many would consider the world's greatest heart surgeon.

Dr Cooley completed his undergraduate education at the University of Texas at Austin, during which he excelled both academically and athletically. Standing a strapping $6^{\prime} 4^{\prime \prime}$, he was an acclaimed basketball player at the varsity level and was instrumental in the team's 1939 Southwest Conference championship win (Figure 2). Dr Cooley would later credit his involvement in the sport for contributing to his success as a surgeon, mentioning that "basketball taught me skills for coping with loss and disappointment.",

Dr Cooley began attending medical school at the University of Texas Medical Branch in Galveston and then transferred to Johns Hopkins School of Medicine in his sophomore year. He graduated from Johns Hopkins in 1944 and then did his surgical internship year and residency there. It was during his time at Johns Hopkins that Dr Cooley met Dr Alfred Blalock, who became a lifelong mentor for Dr Cooley. In 1944, Dr Cooley, then a 24-year-old surgical intern, assisted Dr Helen Taussig and Dr Blalock with the first "blue baby" operation, a revolutionary procedure to alleviate pulmonary stenosis or pulmonary atresia in newborns born with tetralogy of Fallot (Figure 3). ${ }^{2}$ After this experience, Dr Cooley continued to explore treatment options for congenital defects and honed his ability to operate on these smallest of patients.

From 1945 to 1948, Dr Cooley's surgical training was interrupted briefly by his military service, which was still required as the Second World War came to a close. He was stationed in Linz, Austria, and became a captain. It 


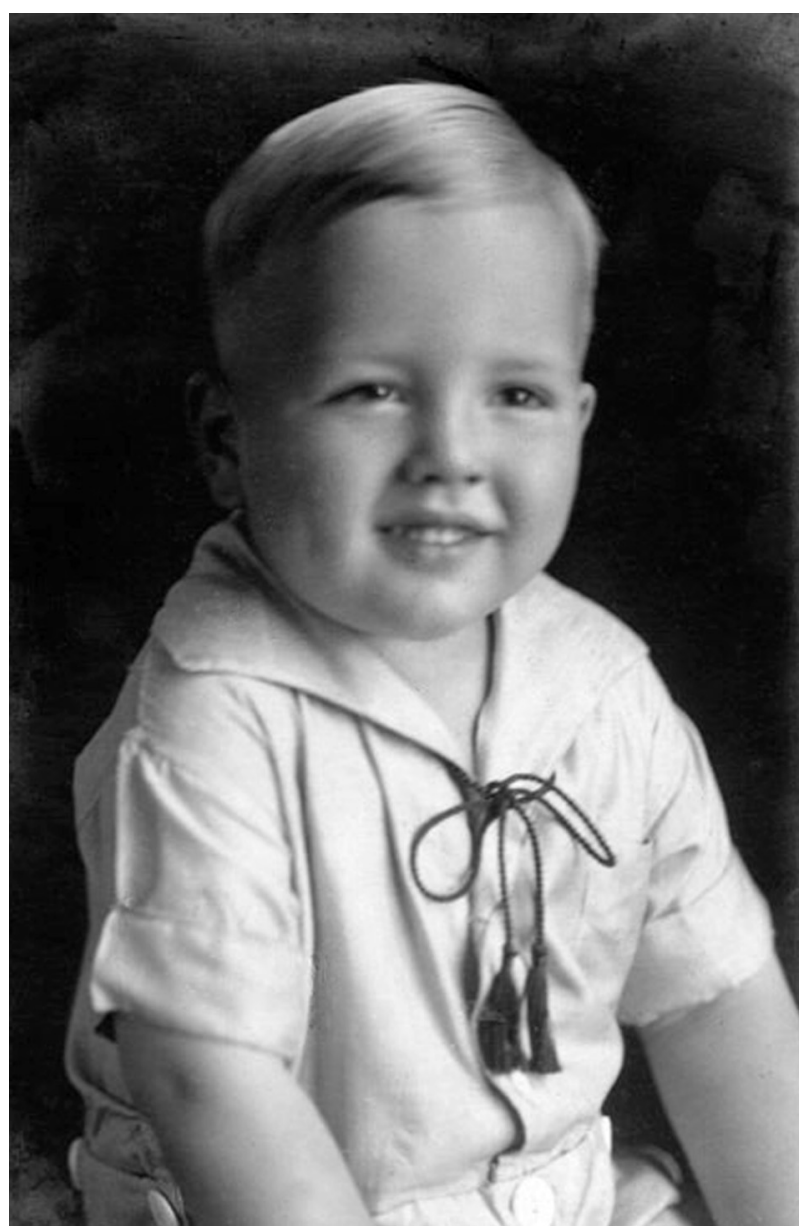

FIGURE 1. Denton Cooley was born on August 22, 1920, into a prominent family with deep ties to Houston. Here, he is shown as a toddler. Used with permission from the Texas Heart Institute.

was a one-of-a kind experience because he was able to perform several types of surgery during this time, ranging from Caesarean sections and deliveries to repairing a complex skull fracture. In 1949, after he had returned to John Hopkins and completed his surgical residency, Dr Cooley had his first opportunity to surgically repair an aortic aneurysm. During the operation, he clamped and excised the saccular thoracic aneurysm and restored aortic continuity with lateral sutures. Later, he would demonstrate this procedure to Dr DeBakey, both inspiring him and setting him on the search for the Dacron fabric that would be used to this day as the graft material for open surgical repair of aneurysms.

At the end of Dr Cooley's surgical residency, Dr DeBakey offered him a position at Baylor College of Medicine (then known as Baylor University College of Medicine, which was a satellite institution of Baylor University). Dr Cooley accepted Dr DeBakey's offer to join the college as an instructor, which was the lowest faculty position, but he decided to defer for 1 year to further round out his training. In the interim, he trained in London,

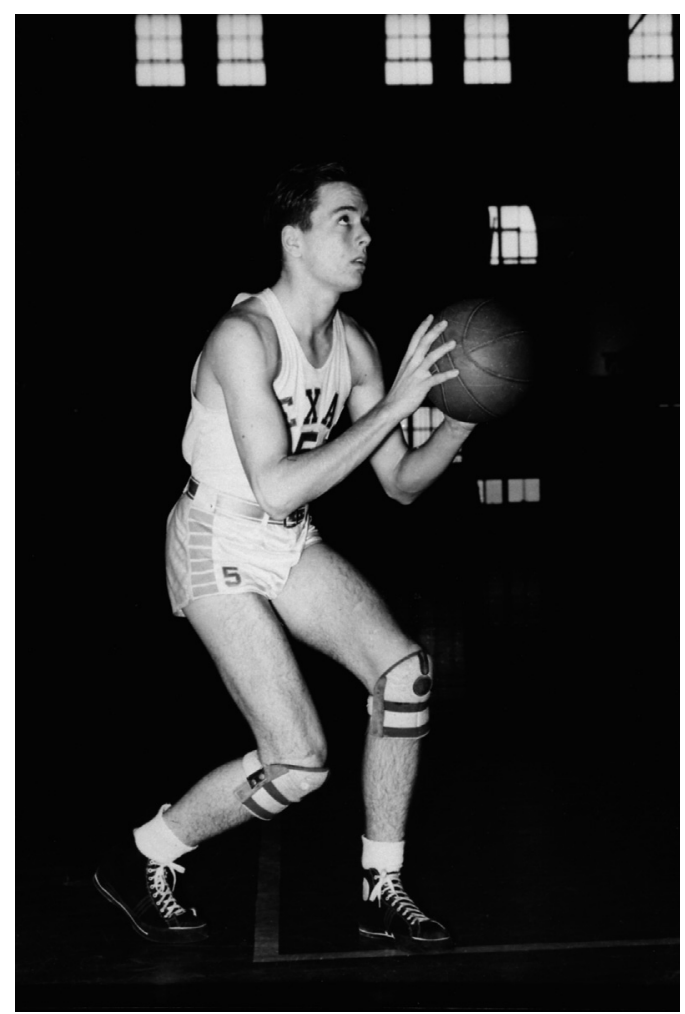

FIGURE 2. Denton Cooley was a skilled athlete and helped lead the University of Texas basketball team to a Southwest Conference championship win in 1939. Used with permission from the Texas Heart Institute.

England, in the service of Lord Russell Brock, who was then the leading expert in mitral valve repair. There, Dr Cooley took over Dr Oswald Tubbs' National Health Service practice at Brompton Hospital and tackled the extremely long patient waiting list by performing twice as many operations per day as the other surgeons-this experience would later prove fruitful.

In 1951, Dr Cooley returned to Houston, where he would spend the rest of his life. During his first years at Baylor College of Medicine (Figure 4), Dr Cooley achieved a considerable number of cardiac and aortic surgical innovations and accomplishments. In 1952, Drs Cooley and DeBakey published their first academic collaboration, a paper that described aortic and great vessel aneurysm repair in 6 patients treated between 1948 and 1951 (including a repair performed at Johns Hopkins in 1950); this paper detailed their widely varied experience and emphasized the use of lateral aortic clamping and resection of saccular aneurysms but not aortic replacement. ${ }^{4}$ After reports were published of homografts being used to replace limited aortic sections with coarctation and abdominal aortic aneurysms, Drs DeBakey and Cooley reported performing the first successful homograft replacement of a thoracic aortic fusiform aneurysm encroaching on the visceral arteries (today, this would be described as an extent 


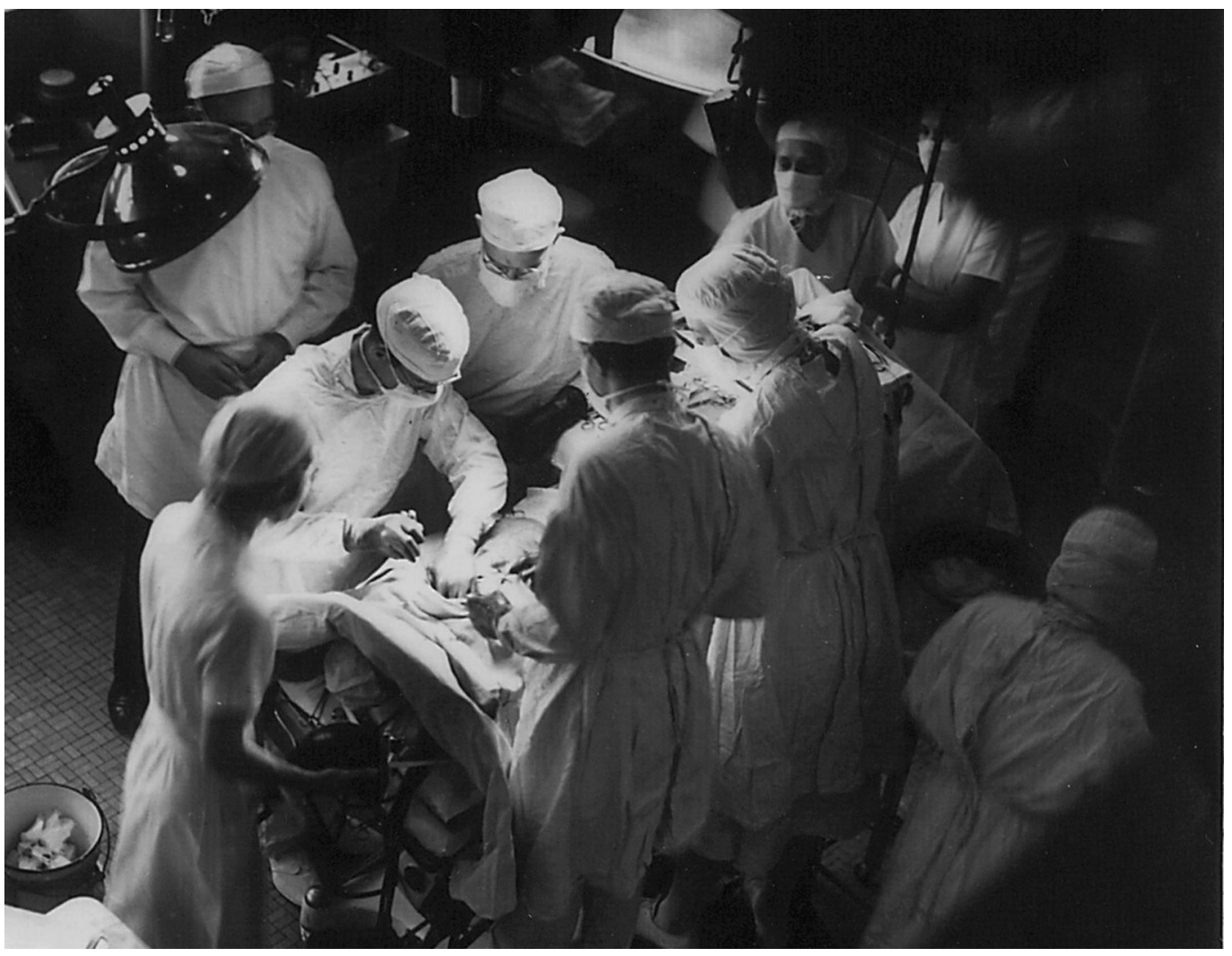

FIGURE 3. The innovative "blue baby" operation was performed at Johns Hopkins Hospital in 1944. Dr Cooley, age 24, is on the right side of the operating table, facing Dr Blalock. Used with permission from the Texas Heart Institute.

I thoracoabdominal aortic aneurysm repair). The procedure was performed at Houston's Methodist Hospital on January 5, 1953. Soon after, Drs Cooley and DeBakey, along with others from Houston, reported a string of surgical firsts in the treatment of aortic disease, ${ }^{6-9}$ including surgical repair of aortic dissection ${ }^{10}$ and aortic rupture, ${ }^{11}$ repairs that had long been thought to be impossible.

In 1954, Dr Cooley began operating at Texas Children's Hospital and St Luke's Episcopal Hospital (which had opened that year), in addition to Methodist Hospital. Soon after joining these institutions, Dr Cooley fabricated an early cardiopulmonary bypass machine, which he modeled after the one he had seen Dr C. Walton Lillehei use, which had been designed by Dr Richard DeWall. With the advent of this new machine, cardiothoracic repairs of greater complexity could be performed in Houston. Soon, St Luke's Episcopal Hospital and Texas Children's Hospital became the center of the most active cardiac surgical practice in the world and remained so for many years thereafter.

It was during this time that Dr Cooley first had the idea for the Texas Heart Institute (THI). He envisioned it as a center that would focus on research and education, supporting the clinical efforts of St Luke's Episcopal Hospital and Texas Children's Hospital but standing as a separate institution. In July of 1962, Dr Cooley presented his proposal for the institution at a joint meeting of the 2 hospital boards, and on August 3, 1962, the charter for the institution was approved. Although Dr Cooley had architectural plans made for a standalone building for THI, fundraising for the proposed building was more difficult than anticipated. Ultimately, Dr Cooley combined his plans with those of St Luke's Episcopal Hospital and Texas Children's Hospital, which were expanding their facilities to accommodate the influx of his patients. Through a trust received from the Ray C. Fish Foundation and additional donors, the building housing the 3 institutes finally had its groundbreaking ceremony on June $26,1967 .{ }^{1}$

The 1960s were a time of continued innovation for $\mathrm{Dr}$ Cooley. Drs Cooley and F. William Blaisdell reported on the relationship between cerebrospinal fluid and aortic clamping with regard to postoperative paraplegia, which remains to this day a significant concern after aortic repairs. ${ }^{12}$ In 1961, Dr Cooley became the first surgeon to attempt open heart surgery on patients of the Jehovah's Witness faith, which he performed by using a nonblood solution (consisting of $5 \%$ dextrose in distilled water) to prime the blood pump. ${ }^{13}$ Although a similar technique had first been used by Dr Nazih Zuhdi and colleagues, ${ }^{14}$ Dr Cooley popularized this approach and was credited for its widespread application (Video 1). By using 


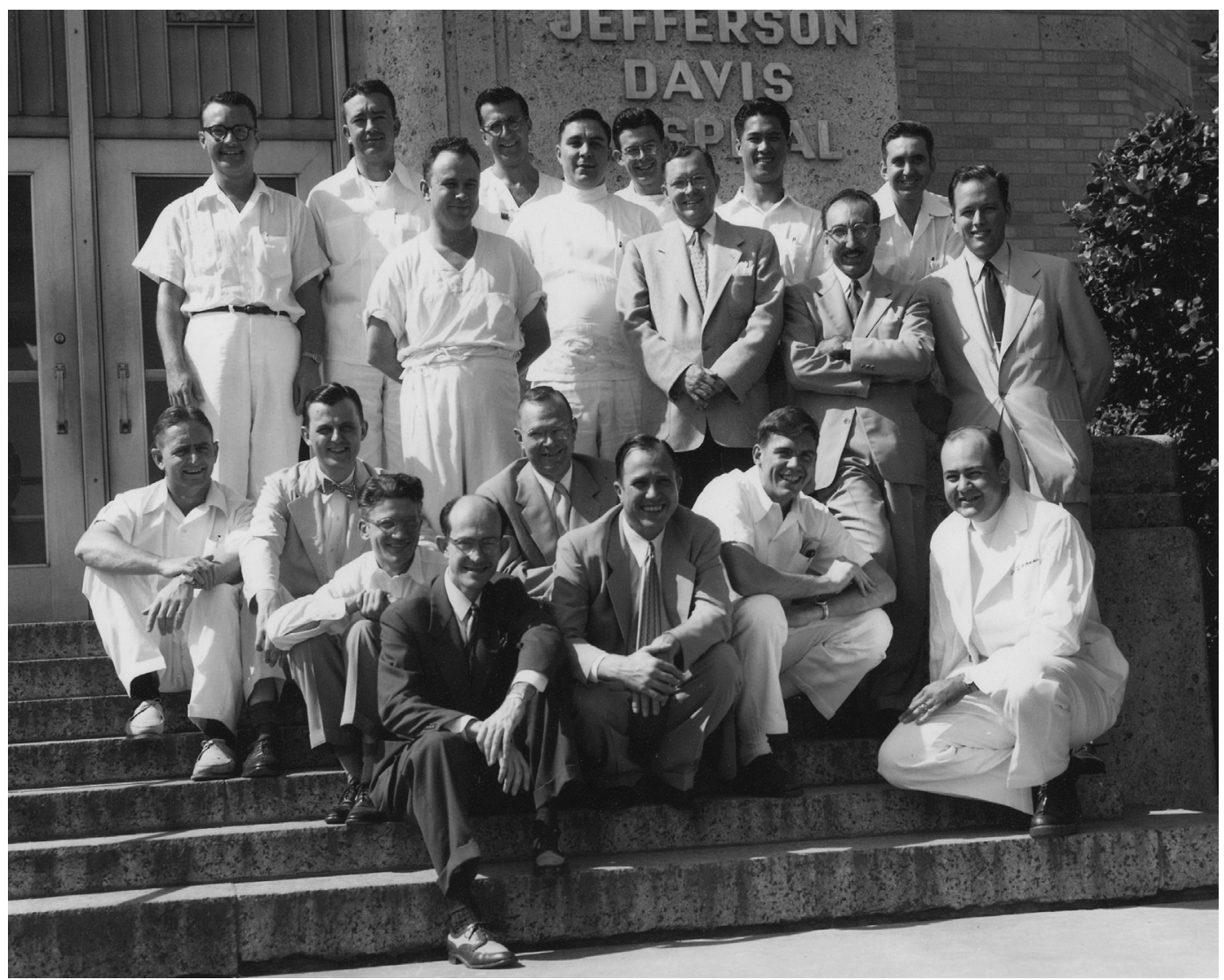

FIGURE 4. Drs DeBakey and Cooley are shown standing side-by-side on the right of the middle row as the Baylor College of Medicine Department of Surgery posed in front of the Jefferson Davis County Hospital in Houston, Texas, in 1952. Used with permission from the Baylor College of Medicine Archives.

hemodilution, Dr Cooley's team became far less dependent on the blood bank, freeing them to perform more operations. In 1965, Dr Cooley's team reached the milestone of performing 1000 cardiopulmonary bypass pump operations in a single year.

On May 3, 1968, roughly 6 months after Dr Christiaan Barnard capitalized on the concept of donor brain death and performed the world's first successful heart transplantation in South Africa, Dr Cooley performed the first successful heart transplantation in the United States. The patient was Everett Thomas, a 47-year-old accountant whose heart had been severely damaged by rheumatic fever. ${ }^{15}$ Dr Cooley was able to obtain a donor heart from a recently deceased suicide victim. After attempting a triple valve replacement and realizing that recovery of Mr. Thomas' own heart was impossible, Dr Cooley proceeded with the transplantation of the donor heart. Mr. Thomas survived for 204 days after the procedure.

By January 1969, Dr Cooley had performed an astonishing 17 heart transplantations (Video 2), including the first attempted combined heart and lung transplantation in a pediatric patient, as well as an attempt to use a sheep's heart out of desperation when no donor heart could be found for his patient. ${ }^{16,17}$ At the time, there was great competition for donor hearts in Houston because heart transplantations were being performed not only by Dr Cooley but also by Dr DeBakey's team (only 300 feet away), which had performed 10 such operations by then. ${ }^{18,19}$ Because of the difficulty of obtaining donor hearts and his disastrous experiment with the sheep's heart, Dr Cooley's attention shifted to the development of a total artificial replacement heart.

Dr Domingo Liotta was recruited to Baylor College of Medicine by Dr DeBakey in 1961. There, Dr Liotta continued his work on artificial hearts, which he had begun years earlier in Argentina. ${ }^{20}$ In time, however, it became clear that Dr DeBakey was more interested in developing a partial artificial replacement heart, later known as the left ventricular assist device (LVAD), to aid recovery after complex surgery rather than developing a total heart replacement. $^{21-23}$ In 1966, the LVAD was first used successfully to provide cardiac support to a patient who had undergone double-valve replacement surgery but could not be weaned from cardiopulmonary bypass. ${ }^{24}$ The LVAD 


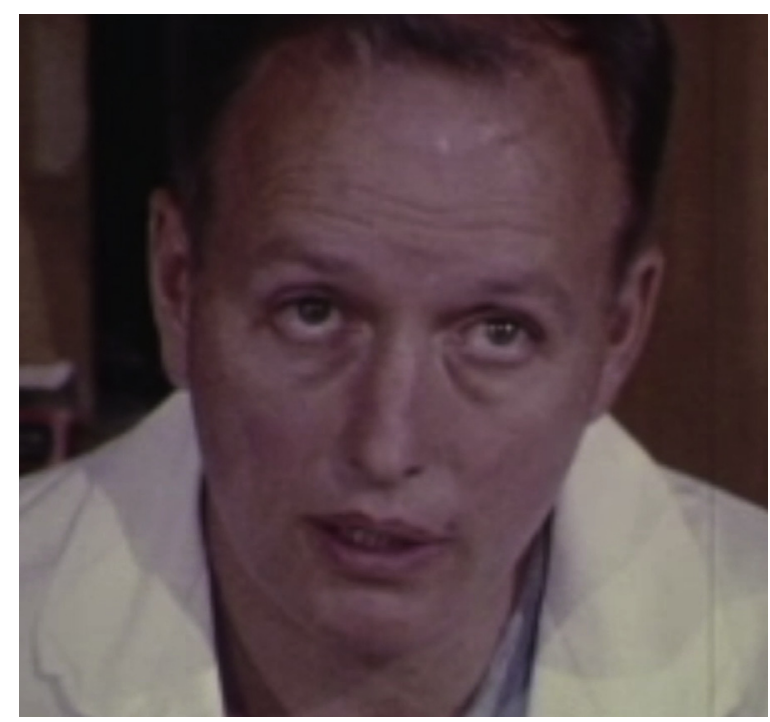

VIDEO 1. Dr Denton A. Cooley discusses the use of a nonblood prime for cardiopulmonary bypass during cardiac transplantation cases at a press conference held in Houston in May 1968. From the KHOU-TV Film Collections (KHOU Box 6802 Reel 08). Used with the express permission of the Houston Metropolitan Research Center at the Houston Public Library. Video available at: http://www.jtcvsonline.org/article/S00225223(17)30174-5/addons.

was used for 10 days until the patient was well enough to cease use. Because Dr Liotta was still interested in pursuing the TAH option, he contacted Dr Cooley about the device. Dr Cooley agreed that the TAH could, indeed, have a place in the hospital's transplantation program. With funds from Dr Cooley's foundation and off-hour assistance from engineers at Rice University, Dr Liotta continued his work on the TAH while simultaneously participating in the ongoing and well-funded efforts to further refine the LVAD device for Dr DeBakey. ${ }^{1}$ Although the TAH and LVAD were quite different conceptually, there were naturally similarities between the 2 devices.

In 1969, a patient named Haskell Karp from Skokie, Illinois, was awaiting heart transplantation at St Luke's Episcopal Hospital. He was suffering from heart failure and was at risk of immediate death if he did not receive a heart soon. With Mr Karp at the brink of death and no donor hearts available, Dr Cooley suggested using the TAH as a bridge until a donor heart could be procured. On April 4, 1969, Dr Cooley proceeded with the operation to implant the TAH, seeing it as the last possible option to save $\mathrm{Mr}$ Karp's life (Figure 5, Video 3). Two days later, the TAH was replaced with a donor heart. Unfortunately, Mr. Karp died on April 8, only 32 hours after receiving the donor heart, due to renal failure and acute pneumonia, which developed because his immune system was severely compromised. ${ }^{25}$

Dr Cooley's decision to proceed with the TAH implantation was not without consequence. His decision

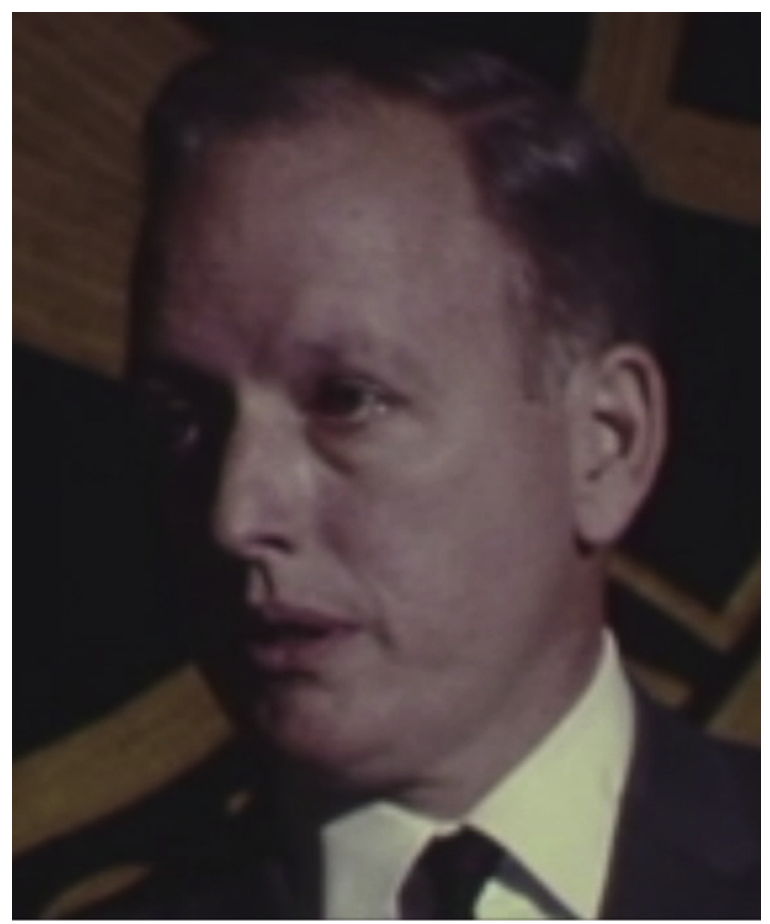

VIDEO 2. Dr Denton A. Cooley discusses his 17th cardiac transplantation case at a Rotary International dinner held in Houston in January 1969. From the KHOU-TV Film Collections (KHOU Box 6901 Reel 02). Used with the express permission of the Houston Metropolitan Research Center at the Houston Public Library. Video available at: http://www.jtcvsonline.org/ article/S0022-5223(17)30174-5/addons.

to implant the device was investigated by several state and national organizations, including the National Heart Institute, Baylor University, and the American College of Surgeons. In the latter half of 1969, after he had been formally censured, Dr Cooley resigned from his faculty position at Baylor and focused on his position at THI. Meanwhile, Dr DeBakey sought greater control at Baylor College of Medicine by formally separating from Baylor University and its board of trustees. He was then installed as the president of Baylor College of Medicine. During the succeeding years, there was a distinct division between THI and Baylor College of Medicine. Nonetheless, both centers flourished, and they both continue to be distinguished institutions in the Texas Medical Center to this day.

The 1970s were marked by groundbreaking efforts by Dr Cooley to expand THI's role as a leading cardiac center. $^{26-32}$ In 1971, Dr Cooley founded the Cullen Cardiovascular Surgical Research Laboratory, with the aim of developing mechanical circulatory assist devices. In 1974, he recruited Dr Tetsuzo Akutsu, a renowned expert in artificial heart development who had participated in pivotal experiments with the TAH under the direction of Dr Willem Kolff at the Cleveland Clinic 

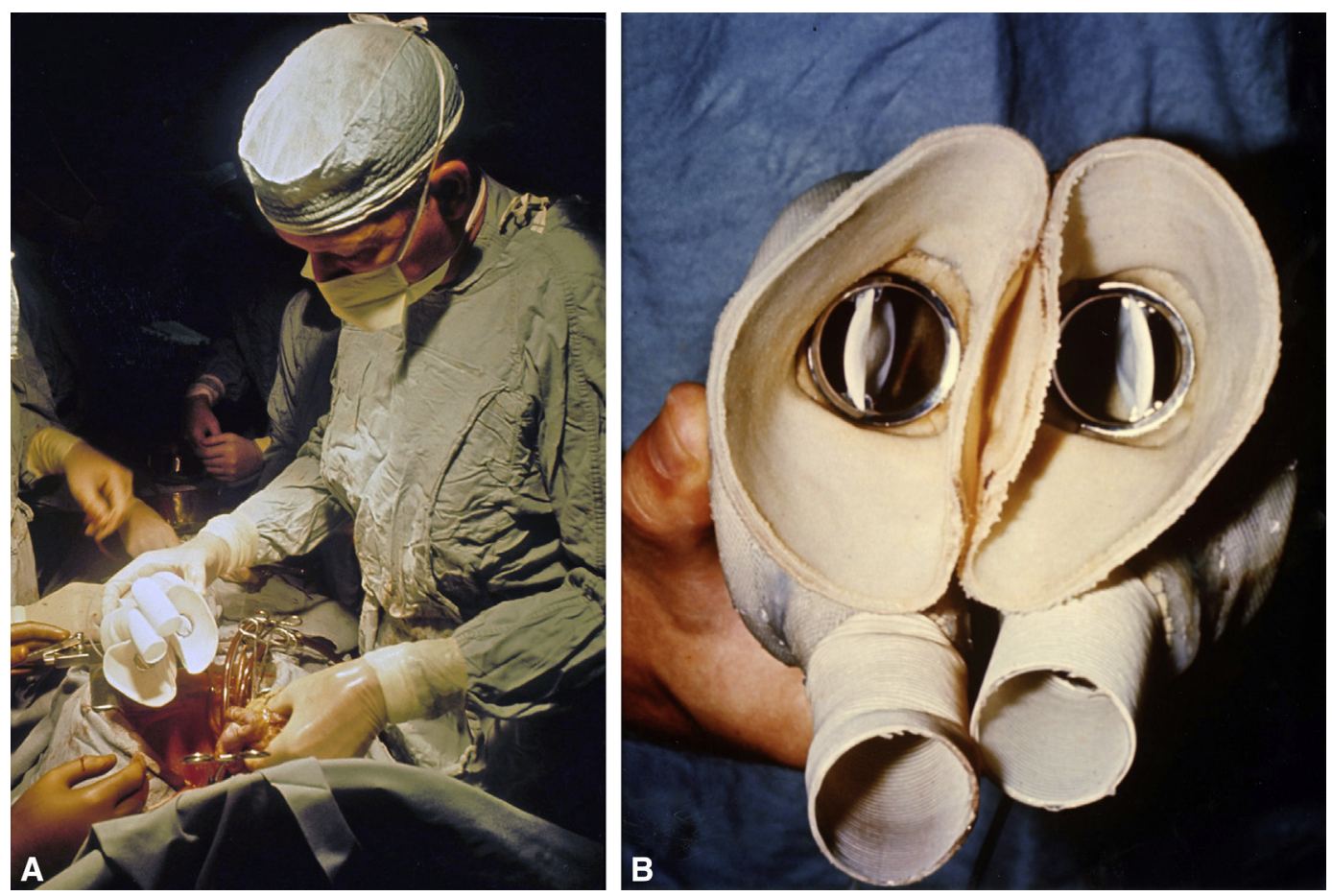

FIGURE 5. Dr Cooley is shown on April 4, 1969 (A) implanting the total artificial heart designed with Dr Liotta and (B) holding the artificial heart to highlight the inclusion of the newly developed Wada-Cutter prosthetic cardiac valves. Used with permission from the Texas Heart Institute.

in the 1950s. Dr Akutsu's work at THI paved the way for Dr Cooley to implant the second TAH (the Akutsu III heart) in a 36-year-old patient as a bridge to transplantation on July

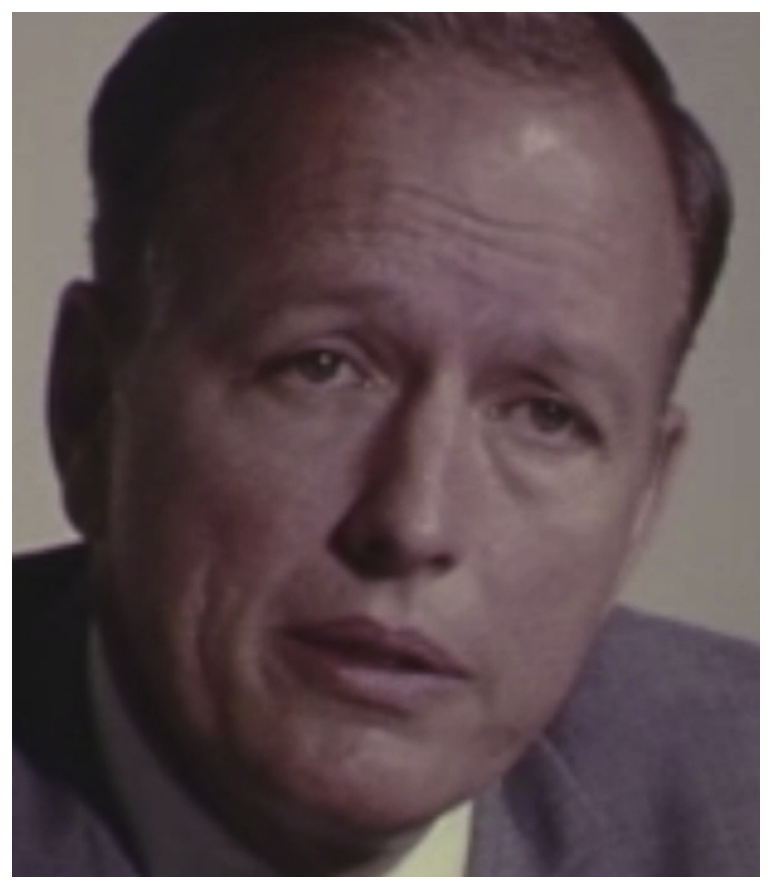

VIDEO 3. Dr Denton A. Cooley defends the use of an artificial heart as a natural progression of patient care during a press conference held in Houston in October 1969. From the KHOU-TV Film Collections (KHOU Box 6904 Reel 21). Used with the express permission of the Houston Metropolitan Research Center at the Houston Public Library. Video available at: http://www. jtcvsonline.org/article/S0022-5223(17)30174-5/addons.
$25,1981^{33}$; however, THI's Cullen Laboratory was focused largely on refining and further developing ventricular assist devices, including devices to temporarily aid in recovery after complex surgery and devices to provide permanent support. In the late 1970s, Dr Cooley implanted dozens of the temporary devices, with 3 patients recovering sufficiently to have them removed. ${ }^{34}$ In time, Dr Cooley yielded these efforts to Dr O. H. Frazier and others at THI. With continued passion, they sought to improve the design of these devices, each generation being revised to be smaller and more powerful, leading to greater clinical success. During Dr Cooley's lifetime, more than 1000 LVADs were implanted at THI and more than 30,000 were implanted worldwide. ${ }^{24}$ Dr Frazier's contemporary efforts in developing LVADs and TAHs have kept THI at the forefront of innovation. $^{35,36}$

On October 27, 2007, Drs Cooley and DeBakey finally reconciled, when Dr DeBakey accepted an honor from the Denton A. Cooley Cardiovascular Society. Their reconciliation was further cemented on April 23, 2008, when, at Dr DeBakey's personal invitation, Dr Cooley attended the ceremony at which Dr DeBakey received the Congressional Medal of Honor. Weeks later, on May 2, 2008, Dr DeBakey presented Dr Cooley with membership in the Michael E. DeBakey International Surgical Society (Figure 6). The feud was clearly over. Within months of this great reconciliation, Dr DeBakey died at age 99. Dr Cooley was solemnly present for Dr DeBakey's memorial service. In the words of Dr Cooley as he reflected on Dr DeBakey, "Ironically, I think our historic rivalry enhanced his reputation, as well as mine, serving 


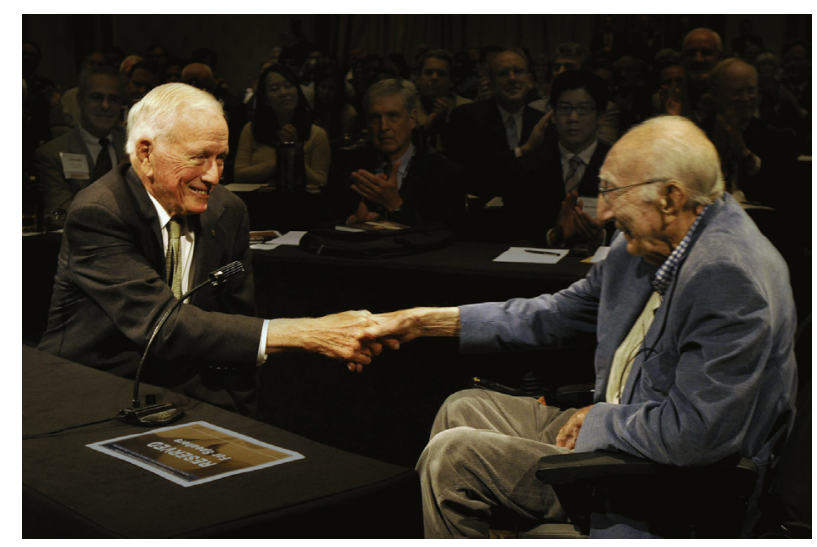

FIGURE 6. An historic feud is resolved. Drs Cooley and DeBakey are shown at the 2008 Joint Session of the Sixth Current Trends in Cardiothoracic Surgery Conference and at the 17th Congress of the Michael E. DeBakey International Surgical Society in Houston, Texas (2008). At the time, Dr DeBakey honored Dr Cooley with membership in the DeBakey Society. Photo taken by Agapito Sanchez. Used with permission from Baylor College of Medicine.

both of our careers well. Most of all, our competitiveness benefitted the Texas Medical Center and its patients. For me, that is the greatest good that could have come from it all."
In addition to all of Dr Cooley's accomplishments in the operating room and hospital, his vibrant family life was a source of great personal pride for him. He married Louise Goldborough Thomas in 1949 after a short courtship. During their 67-year marriage, they welcomed 5 daughters, 16 grandchildren, and 17 great-grandchildren. His devotion to his family life was demonstrated through the building of Cool Acres Ranch, a family vacation home that for years has hosted the Cooley family's get-togethers (Figure 7). Together for nearly 7 decades, Louise preceded her husband in death by a mere 4 weeks at the age of 92 .

Dr Cooley's legacy cannot be abridged adequately. It would be impossible to provide his full story here because of the breadth and scope of his accomplishments. He did not chase excellence in just one field but in several; his accomplishments included expanding therapeutic potential for patients with congenital heart conditions, pioneering heart transplantation, developing prosthetic replacements for heart valves and the whole heart, and establishing new methods for aortic aneurysm repair. Refusing to stand by and tolerate the skyrocketing prices of cardiac procedures in the 1980s, he also developed the first bundled services plan for open heart operations, called CardioVascular Care Providers, which later became the rubric for Medicare pricing models.

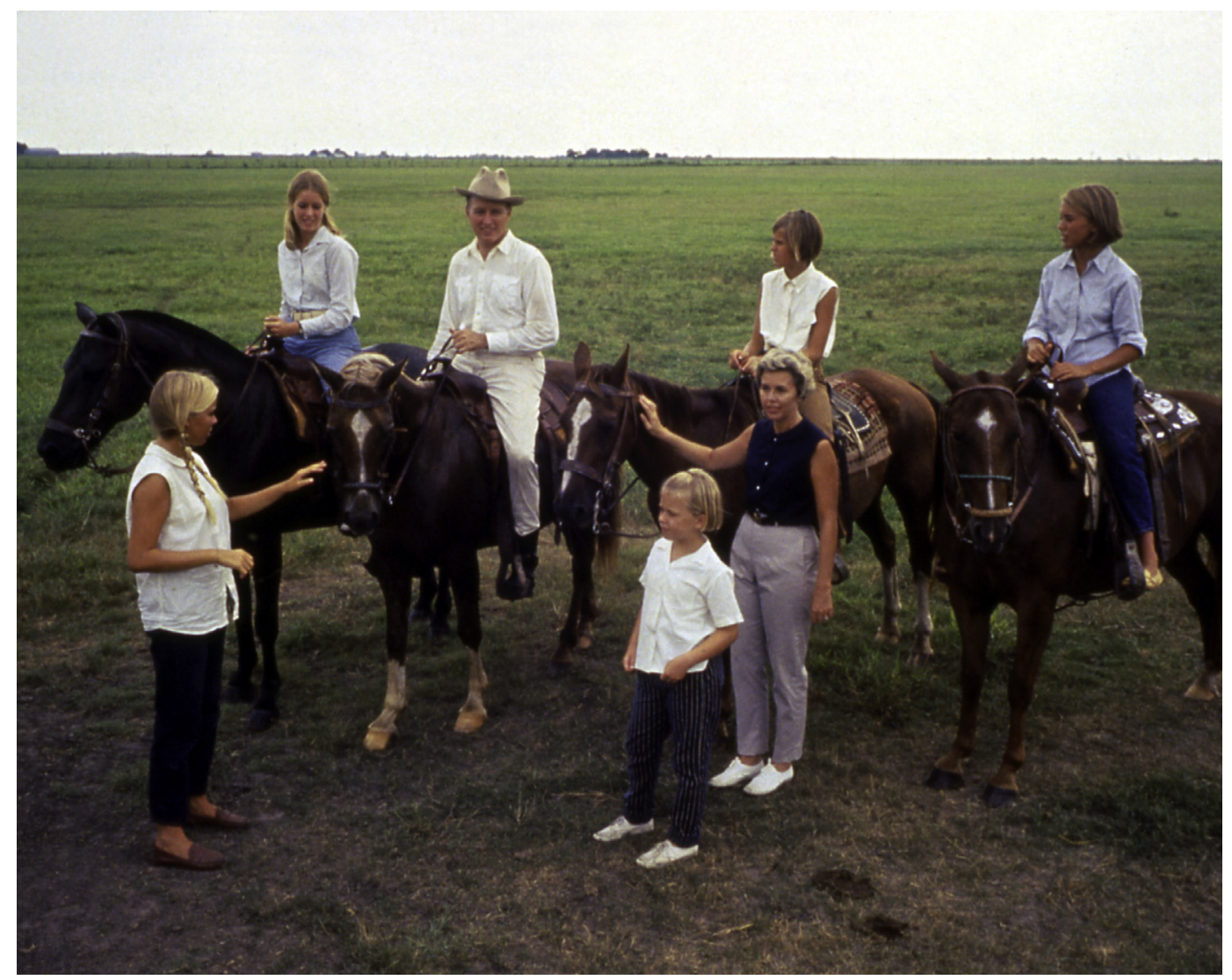

FIGURE 7. Dr and Mrs Cooley at the family ranch, Cool Acres. They are surrounded by their 5 daughters: Mary, Susan, Louise, Florence, and Helen. Used with permission from the Texas Heart Institute. 


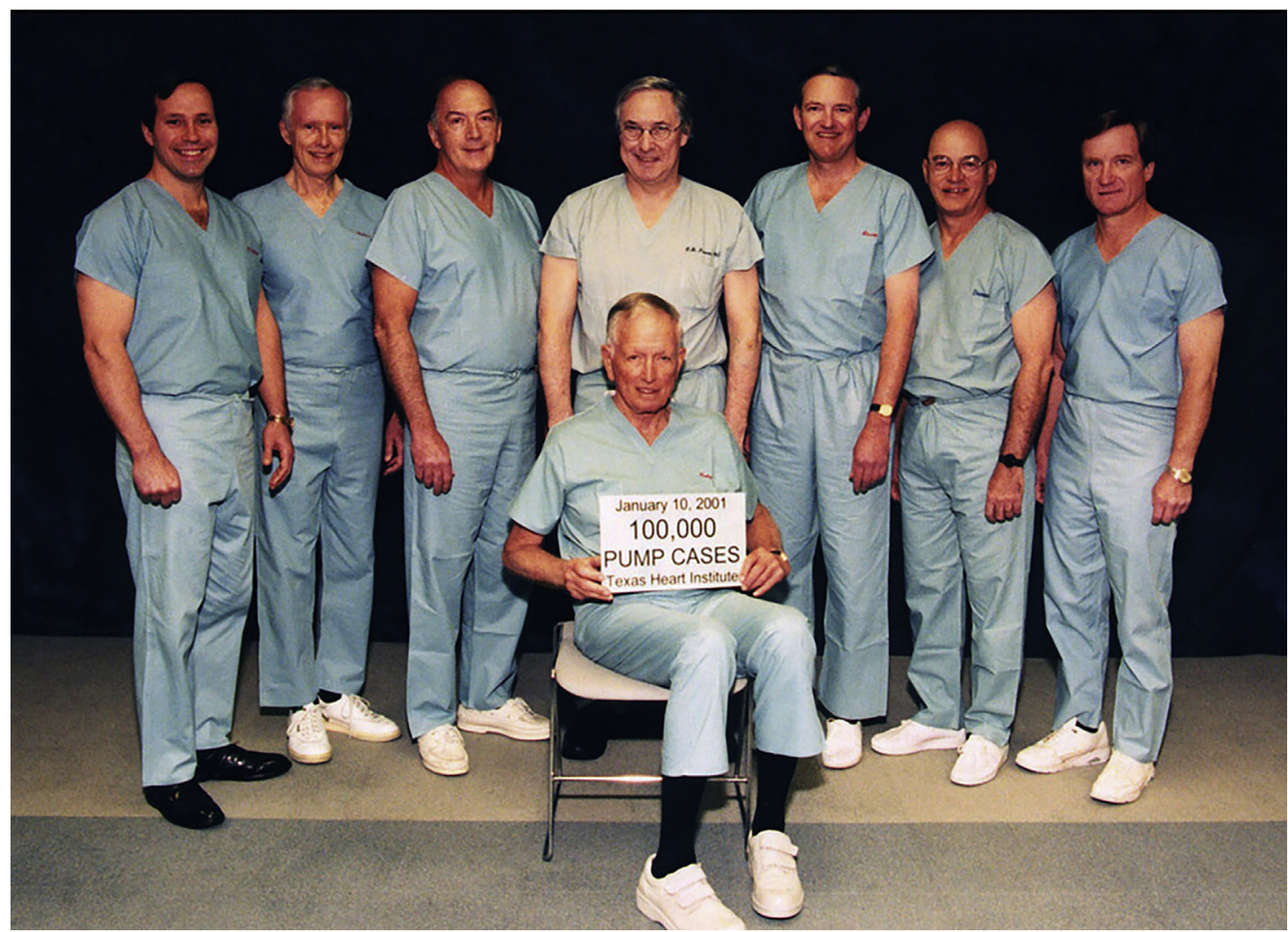

FIGURE 8. Dr Cooley is shown in this photo (center) commemorating the completion of 100,000 open heart surgery cases performed using cardiopulmonary bypass (ie, pump cases) at the Texas Heart Institute on January 10, 2001. Shown in the back row of the photo are Drs C. Hallman, G. Hallman, Reul, Frazier, Livesay, Duncan, and Ott. Used with permission from the Texas Heart Institute.

In 2001, Dr Cooley's THI reached a milestone of 100,000 open heart operations using cardiopulmonary bypass (Figure 8) and continued on to perform more than

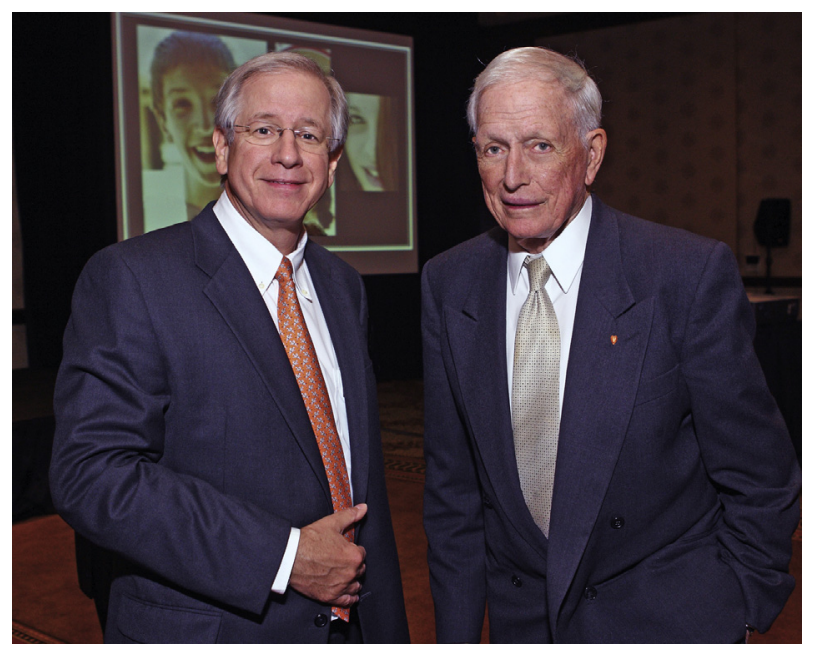

FIGURE 9. Dr Cooley and I attending the 26th annual meeting of The Marfan Foundation, held in Houston, Texas (2010). Photograph taken by Timothy D. Joyce Photography and used courtesy of The Marfan Foundation.
120,000 such operations within Dr Cooley's lifetime. Dr Cooley performed 12,000 aortic aneurysm repairs and 45,000 peripheral vessel operations, published 1400 scientific articles, and held memberships in 30 professional societies, but the numbers cannot tell the whole story. Among his countless honors, Dr Cooley received the Presidential Medal of Freedom from President Reagan in 1984 and the National Medal of Technology and Innovation from President Clinton in 1998. In 2016, I was honored to present Dr Cooley with the Lifetime Achievement Award from The American Association for Thoracic Surgery. Notably, he is the only person to have received both the Lifetime Achievement Award and the Scientific Achievement Award from The American Association for Thoracic Surgery. This honor was especially profound for me because I owe my interest in cardiothoracic surgery to Dr Cooley (Figure 9), who generously gave me a summer job working with his cardiopulmonary bypass pump team when I was just a young college student. While I watched him direct numerous operations each day and effortlessly outwork his team of younger residents and fellows, I marveled out loud at his abilities. I was quickly chided by a young fellow, "What do you expect? Dr Cooley is a surgical athlete!" 


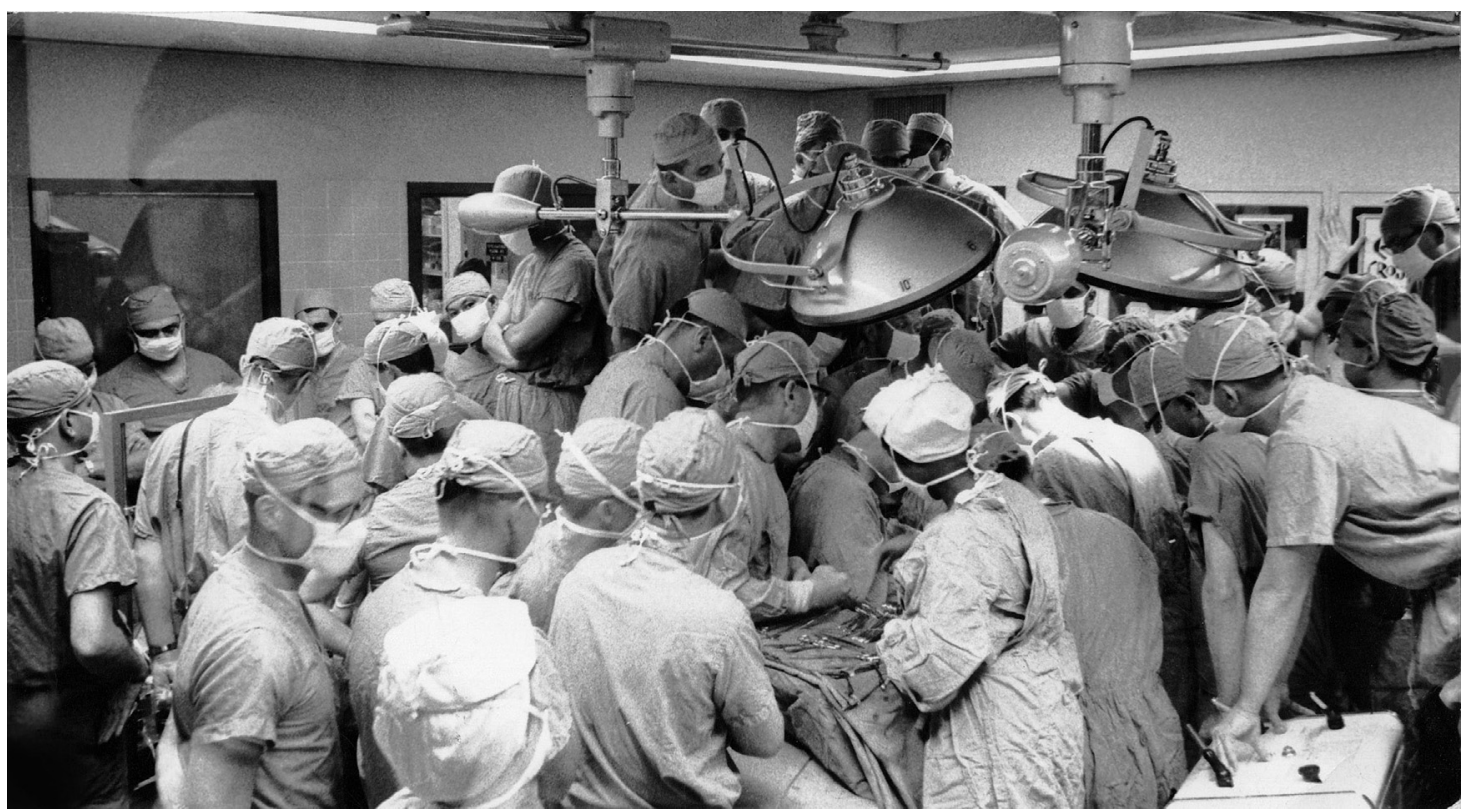

FIGURE 10. Dr Cooley performing a coronary artery bypass procedure in 1970 in front of a crowd of onlookers from 7 nations and 12 states. Used with permission from the Texas Heart Institute.

Dr Cooley's ascension as a surgeon mirrored the ascension of the city of Houston and the Texas Medical Center. Today, it is difficult to fathom the level of fame pioneers like Dr Cooley achieved while they were doing groundbreaking work to develop complex cardiac procedures - the magazines of the day seemed to be filled with images of Dr Cooley's latest achievements. Memorably, he took this fanfare in stride and may have even enjoyed it (Figure 10). Humor was always close at hand with Dr Cooley. He fondly reminisced about a medical liability trial in which he was asked if he considered himself the best heart surgeon in the world. When Dr Cooley quickly replied in the affirmative, he was rebuked for being immodest, to which he quipped, "Perhaps, but remember I'm under oath!' Dr Cooley never relinquished his role as an academic surgeon and spent his whole life proving wrong the words of Dr Blalock, who once expressed concern that Dr Cooley would become just a "society surgeon." Dr Denton A. Cooley clearly achieved much more.

In closing, I present Dr Cooley's favorite poem, which you will find inscribed near the entrance of THI.

\section{A Bag of Tools}

Isn't it strange

That princes and kings,

And clowns that caper

In sawdust rings,

And common people

Like you and me
Are builders for eternity?

Each is given a bag of tools,

A shapeless mass,

A book of rules;

And each must make

Ere life has flown

A stumbling block

Or a stepping stone.

—R. L. Sharpe (1870-1950)

\section{Conflict of Interest Statement}

Author has nothing to disclose with regard to commercial support.

Gratitude is expressed to Heather Leibrecht, MS, ELS, Susan Y. Green, MPH, and Hiruni Amarasekara, MS, for their assistance with the manuscript; Scott A. Weldon, MA, CMI, for assisting with image preparation; JoAnn Pospisil, Director, and Tiffany M. Shreiber, Archivist, of the BCM Archives in the Office of the Chancellor Emeritus; and Ken Hoge and Joe Brewton of Visual Communication Services at THI. Videos 1-3 are used with the express permission of Houston Metropolitan Research Center at the Houston Public Library from the KHOU-TV Film Collections (Box 6902 Reel 5, Box 6802 Reel 8, Box 703 Reel 4).

\section{References}

1. Cooley DA. 100,000 Hearts: A Surgeon's Memoir. Austin: Dolph Briscoe Center for American History; 2012. 
2. Blalock A, Taussing HB. The surgical treatment of malformations of the heart in which there is pulmonary stenosis or pulmonary atresia. JAMA. 1945;128: 189-202.

3. Cooley DA, Debakey ME. Surgical treatment of mitral and aortic stenosis: results of one hundred fifteen valvotomies. JAMA. 1954;155:235-9.

4. Cooley DA, De Bakey ME. Surgical considerations of intrathoracic aneurysms of the aorta and great vessels. Ann Surg. 1952;135:660-80.

5. DeBakey ME, Cooley DA. Successful resection of aneurysm of thoracic aorta and replacement by graft. JAMA. 1953;152:673-6.

6. Cooley DA, Mahaffey DE, De Bakey ME. Total excision of the aortic arch for aneurysm. Surg Gynecol Obstet. 1955;101:667-72.

7. Cooley DA, De Bakey ME. Resection of entire ascending aorta in fusiform aneurysm using cardiac bypass. JAMA. 1956;162:1158-9.

8. DeBakey ME, Crawford ES, Cooley DA, Morris GC Jr. Successful resection of fusiform aneurysm of aortic arch with replacement by homograft. Surg Gynecol Obstet. 1957;105:657-64.

9. DeBakey ME, Cooley DA. Successful resection of aneurysm of distal aortic arch and replacement by graft. JAMA. 1954;155:1398-403.

10. De Bakey ME, Cooley DA, Creech O Jr. Surgical considerations of dissecting aneurysm of the aorta. Ann Surg. 1955;142:586-610; discussion 611-2.

11. Cooley DA, Debakey ME. Ruptured aneurysms of abdominal aorta; excision and homograft replacement. Postgrad Med. 1954;16:334-42.

12. Blaisdell FW, Cooley DA. The mechanism of paraplegia after temporary thoracic aortic occlusion and its relationship to spinal fluid pressure. Surgery. 1962;51: $351-5$.

13. Cooley DA, Beall AC Jr, Grondin P. Open-heart operations with disposable oxygenators, 5 per cent dextrose prime, and normothermia. Surgery. 1962;52: 713-9.

14. Zuhdi N, McCollough B, Carey J, Krieger C, Greer A. Hypothermic perfusion for open-heart surgical procedures. Report on the use of a heart-lung machine primed with five per cent dextrose in water inducing hemodilution. J Int Coll Surg. 1961; 35:319-26.

15. Cooley DA, Bloodwell RD, Hallman GL, Nora JJ. Transplantation of the human heart. Report of four cases. JAMA. 1968;205:479-86.

16. Hallman GL, Leachman RD, Leatherman LL, Bloodwell RD, Nora JJ, Milam JD, et al. Factors influencing survival after human heart transplantation. Ann Surg. 1969; 170:593-602.

17. Cooley DA, Hallman GL, Bloodwell RD, Nora JJ, Leachman RD. Human heart transplantation. Experience with twelve cases. Am J Cardiol. 1968;22: 804-10.

18. Butler WT, Rossen RD, Hersh EM, DeBakey ME, Diethrich EB, Brooks DK, et al. Prevention of rapid immune elimination of anti-lymphocytic globulin in transplant patients. Nature. 1969;224:856-60.

19. DeBakey ME, Diethrich EB, Glick G, Noon GP, Butler WT, Rossen RD, et al. Human cardiac transplantation: clinical experience. J Thorac Cardiovasc Surg. 1969;58:303-17.
20. Liotta D, Taliani T, Giffoniello AH, Deheza FS, Liotta S, Lizarraga R, et al. Artificial heart in the chest: preliminary report. Trans Am Soc Artif Intern Organs. 1961;7:318-22.

21. Hall CW, Liotta D, DeBakey ME. Artificial Heart-Present and Future. Research in the Service of Man: Biomedical Knowledge, Development and Use. Washington, DC: US Government Printing Office; 1967: 201-16.

22. Liotta DS. Michael E. DeBakey and Denton A. Cooley- Mike, the master assembler; Denton, the courageous fighter: a personal overview unforgettable past remembrances in the 1960s. Open J Thorac Surg. 2012;2: $37-45$.

23. Liotta D, Crawford ES, Cooley DA, Debakey ME, De Urquia M, Feldman L. Prolonged partial left ventricular bypass by means of an intrathoracic pump implanted in the left chest. Trans Am Soc Artif Intern Organs. 1962; 8:90-9.

24. Rosengart TK. The 1,000th VAD, the great rivalry, and the grand experiment of the Texas Medical Center. J Thorac Cardiovasc Surg. 2014;147:1745-7; discussion 1747.

25. Cooley DA. First human implantation of cardiac prosthesis for staged total replacement of the heart. Trans Amer Soc Artif Int Organs. 1969; 15:252-63.

26. Cooley DA. The Dutch airlift: a twelve-month surgical experience. Cardiovasc Dis. 1977; 4:335-42.

27. Cooley DA, Okies JE, Wukasch DC, Sandiford FM, Hallmann GL. Ten-year experience with cardiac valve replacement: results with a new mitral prosthesis. Ann Surg. 1973;177:818-26.

28. Cooley DA, Reul GJ, Wukasch DC. Ischemic contracture of the heart: "stone heart" Am J Cardiol. 1972;29:575-7.

29. Cooley DA, Wukasch DC, Bruno F, Reul GJ Jr, Sandiford FM, Zillgitt SL, et al. Direct myocardial revascularisation: experience with 9364 operations. Thorax. 1978;33:411-7.

30. Chiariello L, Meyer J, Wukasch DC, Hallman GL, Cooley DA. Intracardiac repair of tetralogy of Fallot. Five-year review of 403 patients. J Thorac Cardiovasc Surg. 1975;70:529-35.

31. Hallman GL, Cooley DA. Cardiovascular surgery in newborn infants: results in 1,050 patients less than one year old. Ann Surg. 1971;173:1007-12.

32. Ott DA, Cooley DA. Cardiovascular surgery in Jehovah's Witnesses. Report of 542 operations without blood transfusion. JAMA. 1977;238:1256-8.

33. Frazier OH, Akutsu T, Cooley DA. Total artificial heart (TAH) utilization in man. Trans Am Soc Artif Intern Organs. 1982;28:534-8.

34. Westaby S, Bosher C. Landmarks in Cardiac Surgery. Oxford: ISIS Medical Media; 1997.

35. Cohn WE, Timms DL, Frazier OH. Total artificial hearts: past, present, and future. Nat Rev Cardiol. 2015;12:609-17.

36. Frazier $\mathrm{OH}$. Mechanical circulatory assist device development at the Texas Heart Institute: a personal perspective. J Thorac Cardiovasc Surg. 2014;147: 1738-44. 